\title{
Quality management: a compulsory requirement to achieve effectiveness
}

Marta Mas-Machuca

Department of Economy and Business Organization,

Universitat Internacional de Catalunya

C/ Immaculada, 22. 08017 Bacelona (Spain)

Phone: +34 932541800

\author{
Anna Akhmedova* \\ Department of Family Business, IESE, \\ Universidad de Navarra \\ Av. de Pearson, 21. 08034 Barcelona (Spain)
}

Phone: +34932534200

Frederic Marimon

Department of Economy and Business Organization,

Universitat Internacional de Catalunya

C/ Immaculada, 22. 08017 Bacelona (Spain)

Phone: +34 932541800

* E-mail corresponding author: aakhmedova@iese.edu 


\section{Quality management: a compulsory requirement to achieve effectiveness}

Quality management (QM), knowledge management (KM), and organisational culture make up critical resources for sustained competitive advantage of the organisation. Individually, each contributes to perceived organisational effectiveness (POE).

A review of the literature suggests that alignment between these factors is of paramount importance to increase the overall effectiveness of the organisation and that there might be several paths for the organisation to achieve this goal. Therefore, our research aims to determine which combinations of the following organizational resources and capabilities (QM, KM, Values, and Values Fit) should be included to achieve a better POE.

To examine joint effects of several factors, configuration theory logic was adopted. The analysis was relying on complementarity between qualitative and quantitative data. A total of 73 cases were analysed by a qualitative comparative analysis (QCA).

This analysis suggested that alignment between QM and KM, on the one hand; and among QM, values, and value fit, on the other hand, is key to improve POE. Our findings indicate that $\mathrm{QM}$ is a crucial condition of POE. These results offer interesting and useful implications for both academics and managers.

Keywords: Quality management, knowledge management, values, organizational effectiveness, dynamic capabilities. 


\section{1.- Introduction}

Quality Management has been found to be an important aspect for improving organisational effectiveness and achieve sustainable competitive advantage. According to resource-based view (RBV) of the firm, internal characteristics and resources of the company make up critical sources of sustained competitive advantage of organisation (Barney, 1991). Thus, the field of strategic management focuses on how the fit between internal organisational context and strategy explains variances in organisational performance. While internal organisational characteristics (i.e., strategy, structure, culture, and governance) are rather stable (Pettigrew, 1979), it is not clear what mechanism and what paths a company may use to adapt its internal organisational characteristics - resources and capabilities, to the external context, creating sustainable competitive advantage that is difficult to imitate or substitute. This article bases on the complementarity among QM, KM, and culture, as conditions that allow the company to dynamically adapt internal resources to external environment.

Deming (2000), Juran (1992), Feigenbaum (1991), and Crosby (1990) suggest focusing on improving quality to gain competitive advantage. Accordingly, various studies have been trying to establish the connection between total quality management (TQM) and the following different types of organisational performance: (1) quality performance, (2) organisational performance; and (3) innovation performance. From now on, the terms TQM and QM will be used indistinctly, since the term TQM has coined in the eighties and used extensively. First of all, the connection between TQM and quality performance seems to be well-established (Agus \& Hassan, 2011; Zehir, Ertosun, Zehir, \& Müceldilli, 2012). Second, the connection between TQM and organisational performance seems to be confirmed (Akgün, Ince, Imamoglu, Keskin, \& Kocoglu, 2014; 
Fuentes-Fuentes, Albacete-Sáez, \& Lloréns-Montes, 2004; Montes, Jover, \& Fernández, 2003; Sadikoglu \& Zehir, 2010). However, this connection seems to be mediated by internal organisational variables related to human resource management (HRM), innovation performance (Akgün et al., 2014; Sadikoglu \& Zehir, 2010) and learning capabilities (Akgün et al., 2014). Finally, the relation between TQM and innovative performance is the most disputed one, and seems to be related to Knowledge management (KM) (Hung, Lien, Yang, Wu \& Kuo, 2010), organisational learning (Hung, Lien, Fang, \& McLean, 2010) and job satisfaction (Trivellas \& Santouridis, 2009). Thus, it seems that not only that the implementation of TQM is not an easy task for an organisation, but also that its contribution to organisational success might be a function of other variables related with company culture and the management of knowledge.

Adopting a knowledge-based view (KBV) of the firm, previous research suggested that KM might lead to gaining sustainable competitive advantage through constant innovation (Nonaka, 1994). The effect of KM might be both direct and indirect. On the one hand, the direct effect of KM on organisational performance (Choy, Yew \& Lin, 2006; López-Nicolás \& Meroño-Cerdán, 2011; Rasula, Vuksic, \& Stemberger, 2012; Al-Hakim \& Hassan, 2016) and specifically on innovation performance (Alegre, Sengupta, \& Lapiedra, 2013; Gloet \& Terziovsky, 2004; Al-Hakim \& Hassan, 2016) has been established by a variety of studies. On the other hand, indirectly, KM was found to mediate the impact of organisational strategy, culture, and structure on organisational effectiveness (Zheng, Yang \& McLean 2010). Further, KM mediates the effect of organisational context on organisational performance (Dröge, Claycomb \& Germain, 2003). KM effectiveness mediates the effect of HRM on organisational innovativeness (Tan \& Nasurdin, 2011) and KM capacity mediates the effect between strategic Human Resource (HR) and organisational innovativeness (Chen \& Huang, 2009). KM, together 
with HRM and organisational learning, affect OE through increased organisational capabilities (Theriou \& Chatzoglou, 2008).

Thus, it seems that KM affects organisational performance through innovativeness (Alegre et al., 2013; Gloet \& Terziovsky, 2004; López-Nicolás \& Meroño-Cerdán, 2011; Al-Hakim \& Hassan, 2016). However, generally, innovativeness without quality and constant evolution is useless. Similarly, TQM contributes to good organisational results through quality performance, but evolution without innovation cannot be a competitive advantage in the long run. Both TQM and KM are embedded in organisational culture; thus, organisational values that are consistent with these practices and accepted by employees, play key roles on whether TQM and KM would achieve the desired outcome.

Thus, KM, QM, and culture are key organisational assets, which have been studied in their relation to organisational effectiveness. However, joint effect of those assets on organisational effectiveness remains understudied. It is important to close this gap in literature, because these resources and capabilities are interrelated, and their effectiveness is conditioned to fit among the elements. Therefore, the ultimate goal of this study is to determine which combinations of components of the following organizational resources and capabilities (QM, KM, Values, and Values Fit) should be included to achieve a better POE. To answer this question, we use a sample of 73 companies located in Spain. Next section describes the literature review, focusing on interrelations among $\mathrm{KM}$, culture and $\mathrm{QM}$ and their joint relation on $\mathrm{OE}$.

\section{2.- Theoretical background}

The resource-based view posits that firm competitiveness comes from a unique bundle of tangible and intangible resources that are valuable, rare, imperfectly imitable, 
and sustainable (Barney, 1991). With the aim to find specific mechanisms or pathways that a company might use to transform internal context, resources, and capabilities into a sustained competitive advantage, the literature review was divided into three parts: (1) the connection between QM and organisational effectiveness; (2) the connection between KM and organisational effectiveness; and (3) the connection between culture and organisational effectiveness.

2.1.- Quality management and organisational effectiveness

QM improvement is a highly desired organisational objective that is related with organisational performance (Ahire, Golhar, \& Waller, 1996; Dow, Samson, \& Ford, 1999; Samson \& Terziovski, 1999). While there exists a robust evidence of a relation between TQM and organisational performance, the relation between TQM and organisational innovativeness is not evident (Prajogo \& Sohal, 2001). On the one hand, TQM might establish a system and culture that favours innovation (Dean \& Bowen, 1994; Kanji, 1996; Martínez-Costa \& Martínez-Lorente, 2008). The opposing argument provides evidence that TQM might hinder organisational innovativeness by limiting it to just incremental innovativeness or reducing it to present customer desires (Prajogo \& Sohal, 2001). Further, TQM could hinder creativity due to standardisation, or limit innovative capacity due to cost efficiency (Harari, 1993; Leavengood \& Anderson, 2011; Prajogo \& Sohal, 2001). This confusion might be explained by a fact that the relation between TQM and organisational performance might also depend on other factors or combination of factors. In the similar vein, Prajogo and Sohal (2006) suggest that TQM plays the mediating role between strategy and company performance; therefore, it should be complemented by other resources to more effectively leverage organisational performance, particularly innovation. 
To date, the link between TQM and KM was explored more theoretically (Hsu \& Shen, 2005; Lin \& Wu, 2005; Ooi, I, \& Yee-Loong Chong, 2009), than practically (Molina, Montes, \& Fuentes, 2004). From the theoretic point of view, TQM and KM share a number of similarities, but also differences (Hsu \& Shen, 2005) that make possible their effective complementary adoption within the company. In theory, a correct implementation of KM practices, in every area of QM, might set conditions for increased effectiveness and sustained innovativeness of the company (Linderman, Schroeder, Zaheer, Liedtke, \& Choo, 2004).

\section{2.- Knowledge management and organisational effectiveness}

$\mathrm{KM}$ is recognised as an important tool in sustaining competitive advantage and value creation for stakeholders of the organisation. Themes relating KM to competitiveness, innovativeness, and effectiveness increasingly appear in the academic literature (Carneiro, 2000; McAdam, 2000; Meso, Troutt, \& Rudnicka 2002; Stähle \& Hong, 2002). Several empirical studies confirm a significant relationship between KM and increased organisational performance (Darr, Argote \& Epple, 1995; McEvily \& Chakravarthy, 2002; Zheng et al., 2010).

However, it should be noted, that while in some studies, the evidence holds that KM has a direct effect on effectiveness (Darr et al., 1995), in others, KM has a mediate effect (Zheng et al., 2010). Thus, socialisation and externalisation of knowledge might be affected by cultural expectations. Which opinions are shared and what information is retained, would depend on general cultural context and on a firm's specific cultural context (Zheng et al., 2010). Further, knowledge combination and knowledge internalization would depend on the speed of the knowledge flow. Finally, which information would be paid attention to would depend on the policy of the company. 
Because the nature of knowledge varies depending upon knowledge processes, locations or time (Nonaka, Toyama, \& Konno, 2000; Wiig, De Hoog, \& Van Der Spek, 1997), KM is dynamic in nature. Within a variety of knowledge processes (i.e., creation, manifestation, use, and transfer (Wiig, 1995)), knowledge creation is a critical competitive tool that enables a company to achieve sustainable competitive advantage (Choi \& Lee, 2002; Nonaka et al., 2000). Organisational capability to create knowledge and the overall effectiveness of KM systems, depends on their fit with external and internal characteristics of the company (Choi \&Lee, 2002). Although KM, in general, is considered in this research, KMC - theoretically relied on Nonaka's (1994) SECI model - lies at the heart of this investigation, primarily because the process of knowledge creation is a proxy of the effectiveness of KM systems.

\section{3.- Culture and organisational effectiveness}

Corporate culture has received much attention in the last decades, due to its potential impact on organisational success. Since the pioneering work of Deal and Kennedy (1982), many scholars intended to trace specific values, philosophies, and employees' attitudes that might lead to superior organisational performance. Indeed, it was found that certain types of culture might enhance organisational performance (Denison, 1990; Kanter, 2011; Van der Post \& De Coning, 1998) and might be related with the implementation of organisational strategy (Rashid \& Anantharaman, 1997). Organisational culture refers to 'shared' assumptions, values, and norms (Schein, 1985). Therefore, there should be a match between organisational values and employee values in order to create an organisational commitment, which results in increased job performance and organisational effectiveness (Ali, Rehman, Ali, Yousaf, \& Zia, 2010). 
QM, in its core, consists of certain values and practices that are supposed to benefit the organisation (Hellsten \& Klefsjö, 2000). Therefore, whether QM will have the expected positive organisational effect, depends on whether the organisational culture is integrated with values and practices of TQM (Prajogo \& McDermott, 2005). While many positive examples of such integration exist (Souza-Poza, Nystrom, \& Wiebe, 2001; Zu, Robbins, \& Fredendall, 2010), there is some evidence that culture mismatch might be one of the main causes of problems related with implementation of TQM (Prajogo \& McDermott, 2005). Several studies explore this area, suggesting that organizational culture based on specific values (Gimenez-Espin, Jimenez-Jimenez \& Martínez-Costa, 2013; Rezaei, Mardani, Senin, Wong, Sadeghi, Najmi, Shaharoun, 2013) and specific dimensions of organizational culture (Tomic, Brkic, Karapetrovic, Pokrajac, Milanovic, Babic \& Djurdjevic, 2017) might have effect on whether the implementation of QM practices will be successful.

Culture not only conditions QM, but also KM. Existing literature implies a positive relationship between organisational culture and KM (Brockman \& Morgan, 2003; Davenport \& Prusak, 1998; Young, Sapienza, \& Baumer, 2003). In this sense, culture does not have a direct influence on organisational performance, but it might condition the effectiveness of KM (Ahmed, Loh \& Zairi, 1999; David \& Fahey, 2000). The effectiveness of KM and its relationship with organisational performance, depends on how the external and internal information is absorbed, processed, and integrated; it also depends on how sense is constructed from different pieces of information. Furthermore, it is organisational culture that plays a key role in fostering or hindering the process of information sharing and meaning creation.

\section{4.- An integrative research model}


Integrating insights from the literature streams that were reviewed above, it is logical to suggest that, although, KM, QM, values, and value fit—-taken separately—play important roles in the POE, considering these elements of organisational resources and capabilities together might show several paths to attain POE and demonstrate possible synergies between these elements that companies might use to improve their results or find mistakes in their implementation. This line of reasoning leads to a conceptual framework based on the configuration theory. As its fundamental premise, the configuration theory posits that the same set of causal factors can lead to different outcomes, depending on how such factors are arranged. Three principles underlie the configuration theory: (1) outcomes of interest rarely result from a single causal factor; (2) causal factors rarely operate in isolation; and (3) the same causal factor may have different and even opposing effects, depending on the context (Greckhamer, Misangyi, Elms, \& Lacey, 2008). Thus, the main proposition of this study is as follows:

To explore how resources and capabilities of the company (QM, KMC, VA, and VF) might be better combined to improve perceived organisational effectiveness (POE).

The research model is presented in Figure 1.

$$
<<\text { Insert Figure 1 }>>
$$

\section{3.- Data and methods}

A mixed methodology of data gathering was used. First, a quantitative study, consisted of an online survey, was carried out by means of Survey Monkey TM. The principal method of analysis for this study was qualitative comparative analysis (QCA), which will be presented further. QCA is often used as complementary to multiple case study, as a tool to quantify, simplify, and summarise the qualitative findings (Schneider \& Wagemann, 2010). Implementing this approach to data obtained in a survey might have a limit to, some extent, understanding cases by researchers, as well as their ability to select 
cases and conduct the analysis through different stages. For this reason, in addition to quantitative survey data, qualitative data was collected through 4 in-depth interviews, conducted and recorded in Skype TM. In the next section the quantitative sample is described.

\section{1.- Sample and procedure}

The study was based on a convenience sample of Spanish companies (total 832) that were using University's (Universitat Internacional de Catalunya (UIC)) focused programs. The sample of the study included employees from different management levels. The responses were collected in one wave, between April and May 2017. After the exclusion of incomplete questionnaires, data for the analysis comprised of 73 valid surveys (i.e., a response rate of $8.8 \%$ ). Companies that responded to the survey represented different industry sectors, were relatively old (median age 52 years, oldest -80 years and the youngest 28 years) and pertained to small-median size (median number of employees 19,6, highest number of employees -85 and smallest -2 ). At individual level, the sample showed a big gender bias, as only $17.8 \%$ of the respondents are women and the majority (i.e., $72.6 \%$ ) were dedicated to strategic management (see Table 1).

$$
<<\text { Insert Table 1 }>>
$$

\section{2.- Measures}

To measure each of the five constructs, validated measurement instruments were used. For each construct, a Principal Components Analysis (PCA) was performed, forcing to extract a single factor in each PCA to ensure that each construct represents a homogeneous factor. In addition, the only items that scored higher than 0.7 were retained for further research, confirming convergent validity of each measure. Cronbach's alpha coefficient and composite reliability in every case exceeded the threshold value of 0.7 for 
internal consistency (see Table 2). The description of measurement constructs can be found in the Appendix.

$<<$ Insert Table 2>>

QM was assessed by the EFQM model TM (EFQM, 2012a, 2012b), which consists of nine affirmations assessed on a five-point Likert scale. After an Exploratory Factor Analysis (EFA), six items were selected to operationalise the condition: 'quality management'.

KM was measured by a Knowledge management creation (KMC) scale, based on Nonaka's (1994) SECI model, with several items updated according to the current environment (Becerra-Fernandez \& Sabherwal, 2001; Li, Huang, \& Tsai, 2009). The KMC scale was recently validated by Mas-Machuca, Malbašić, and Marimon (2017), which borrowed items from mainly from SECI model, consists of sixteen items measured on a five-point Likert scale. After EFA, eight out sixteen items were retained to operationalise the condition: 'knowledge management creation'.

Culture was measured, based on two constructs: (1) values; and (2) values fit. Values were measured based on a categorisation, proposed by Cardona and Rey (2008) and further elaborated by Malbašić, Marimon, and Mas-Machuca (2016), which suggests four main dimensions of organisational values: (1) relational values, (2) development values, (3) contribution values, and (4) business values. Measurement instrument consisted of sixteen items (i.e., four for each category of values) assessed on a five-point Likert scale. After EFA, eight items were retained to operationalise the condition: 'values'.

There are two possible kinds of measurement for organisational value fit: (1) direct (i.e., subjective) measures, where respondents directly estimate similarities between organisational and personal values; and (2) indirect (i.e., objective) measures, where respondents, from the first step, estimate the values of the organisation (Yaniv \& Farkas, 2005). This study uses direct (i.e., subjective) measures, adopted from Cable and 
DeRue (2002). Thus, the value fit was measured by three items on a five-point Likert scale. After EFA, all three items were retained as valid measures of the condition: "value fit'.

Finally, the measure of POE was adapted from Lee and Choi (2003). The original instrument was employed consisting of five items assessed on a five-point Likert scale, which assess the perceived performance comparing to the competence. After EFA all five items were retained to operationalise the outcome: 'perceived organisational effectiveness'.

\section{3.- Method}

QCA is an analytical approach that offers advantages when there is a need to take a holistic view on a complex phenomenon. QCA uses Boolean algebra and set theory logic to find logical conclusions that a data set can support. The 'interaction logic' is different in QCA, compared to Multiple Regression Analysis (MRA) or Structural Equation Modelling (SEM). QCA is used to systematically compare a small or intermediate number of cases without losing their complexity, bridging qualitative and quantitative analysis. QCA studies the causal complexity by assuming that cases represent some mix of causes and conditions (not independent variables) that correspond to the outcome (not dependent variable).

QCA requires calibration, which is the transformation of outcome and explanatory conditions into sets, according to the degree of membership in a specific condition (Ragin, 2008). This study uses fuzzy-set QCA, which employs a fuzzy-set value range from full membership (1) to full non-membership (0). The calibration is done by determining membership value and transforming original values into membership values. Because 
standardised factors, obtained from EFA, were used, the calibration decision was based on data distribution. The process of calibration is reflected in Table 3.

$<<$ Insert Table $3>>$

Data analysis in QCA starts by defining property space, which is then converted to a 'truth table' by a cross-case comparison of memberships between causal sets (i.e., motivation and barriers) and an outcome set (i.e., position) (Ordanini, Parasuraman, \& Rubera, 2014). Consistency was used to evaluate configuration of the conditions that can be sufficient to achieve high-position. Because only a few inconsistent cases are allowed, the consistency threshold was set to 0.8 , as recommended by Ragin (2008). Once all configurations were identified, a mathematical reduction provided three types of solutions: (1) complex, (2) parsimonious, and (3) intermediate. It should be noted that the high number of logical remainders can be a problem. There was a small number of logical reminders in the truth table, as the analysis was based on a relatively high number of empirical instances (i.e., fourteen out of sixteen possible).

\section{4.- Results}

QCA distinguishes between necessary and sufficient conditions. While a sufficient condition is the one that securely leads to the outcome, there might be other conditions that also lead to the outcome but unable to achieve POE. Thus, a necessary, but not sufficient, condition is the one that does not lead to the outcome; however, it is shown in majority of conditions that lead to the outcome (i.e., both sufficient and not).

$<<$ Insert Table $4>>$

Before proceeding with an analysis of sufficient conditions, the analysis of necessary conditions should be undertaken (Schneider \& Wagemann, 2010). A causal condition is called 'necessary' if the instances of the outcome constitute a subset of the instances of the causal condition (Ragin, 2006, p. 297). Conventionally, a condition or a combination 
of conditions is called 'necessary' or 'almost necessary' if the consistency score exceeds the threshold of 0.9. Additionally, a necessary condition might be trivial or non-trivial (Schneider, Schulze-Bentrop, \& Paunescu, 2010). A necessary condition that is trivial occurs in all cases, independently of the presence or absence of the outcome. Thus, a trivial necessary condition would yield a coverage rate near zero (Ragin, 2006, pp. 302$303)$.

As it can be seen from Table 4, no single condition or its negation exceeds the 0.9 threshold. However, one expression of the three conditions (i.e., values, value fit, and $\mathrm{KM}$ ), joined by a logical 'or', achieved a consistency score of higher than 0.9. Specifically, this means that values or value fit might play a functional substitute for KM. The expression is non-trivial (i.e., high coverage). In practice, this means that neither values, value fit, nor KM cause the outcome, but they do appear as a part of the causal expression. On the other hand, one can learn that QM is not a functional substitute for $\mathrm{KM}$, and vice versa, as the consistency of this expression QM 'or' KM is less than 0.9.

$<<$ Insert Table $5>>$

Once the analysis of necessary conditions was performed, we were able to proceed with the main analysis of sufficient conditions. A causal condition can be considered 'sufficient' to lead to the outcome if, for each case, the fuzzy membership value of the causal condition $(\mathrm{X})$ does not exceed the fuzzy membership value of the outcome $(\mathrm{Y})$ (Ragin, 2000, p. 235). Following the analysis of necessary conditions, an analysis of sufficient conditions was performed by analysing configurations obtained after mathematical reduction. Ragin (2008) suggests superiority of intermediate solutions that use only easy logical remainders when simplifying the solution; although, in this case, there were very few reminders. The intermediate solution is presented in Table 5. The notation for solution table follows the approach of Ragin and Fiss (2008), where white circles $(\circ)$ represent the absence of a condition, black circles $(\bullet)$ represent the presence 
of a condition, and blank cells represent ambiguous conditions.

The model had a good fit. Solution coverage was 0.65 , which is higher than the recommended value of 0.45 (Ragin, 2008). This means that, collectively, the two pathways explain $65 \%$ of increased POE. Consistency shows whether the outcome can be produced, regularly, by the solution (Schneider \& Wagemann, 2012). Consistency was 0.77 , which is higher than the recommended value of 0.74 (Ragin, 2008).

The first pathway suggests that the implementation of QM and KM set positive conditions for the increased POE. This solution explains $61 \%$ of cases, suggesting the high empirical relevance of this solution. Fifteen percent of cases are explained by this solution as it is. The second solution appears in $50 \%$ of cases, and taken as is, it only explains $4 \%$ of cases, making it less empirically relevant than the first one.

\section{5.- Discussion}

Because more than one solution appears to be sufficient for the outcome, results suggests that no unifying causal path is able to predict the outcome. The resulting model did not have any condition that should be absent, meaning that all conditions are necessary for the outcome (i.e., increased POE). Because QM was present in both pathways, it can be viewed as an indispensable condition of POE. Values, values fit, and KM are present in one of pathways, suggesting that either values and their value fit or KM is important for increased POE.

5.1.- Quality management and knowledge management as predictors of perceived organisational effectiveness

The first solution highlights the importance of developing dynamic capabilities based on QM and KM. This solution emphasises the complementarity between 
continuous improvement (i.e., QM) and innovativeness (i.e., KM). Through the constant conversion of tacit knowledge, gained into explicit knowledge, and having to compromise with the quality, better strategies are generated, providing competitive advantage of the company.

QM and KM are inherently related (Lim, Ahmed \& Zairi, 1999; Zhao \& Bryar, 2001) and complement each other in a way that QM leads to increased effectiveness (Hsu \& Shen, 2005, p. 359), while KM leads to innovation. As it was stated in the literature review, QM implemented without $\mathrm{KM}$ strategies could hinder creativity, due to standardisation, or limit innovative capacity due to cost efficiency (Harari, 1993; Prajogo \& Sohal, 2001). Implemented together, these strategies may complement each other, leveraging organisational performance, increased effectiveness, and innovativeness.

Further, the KBV of the firm provides another theoretical perspective in understanding how QM leads to POE through KM. According to this view, knowledge is the resource of competitive advantage of the firm that improves with performance (Grant, 1996). If QM practices lead to knowledge creation, then there is a link between QM and $\mathrm{KMC}$, on the one hand, and POE, on the other. Linderman et al. (2004) provides an extensive conceptual study on how KM and the SECI model of Nonaka (1994) is related to two QM models: first, by Sitkin, Sutcliffe, and Schroeder (1994); and, second, by Dean and Bowen (1994). According to their conceptualisations, each conversion of tacit knowledge into explicit knowledge (i.e. KMC through SECI) should be done in every area of QM. Thus, QM practices should allow knowledge to be constantly created to improve firm performance (Linderman et al., 2004). The following manager interview quote highlights the relevance of quality and KM: "In our mission, quality is equal to excellence and to be a benchmark against the competition. That leads to all employees wanting to do things better. This happens when the person has a sense of contribution, 
makes their abilities are put into play and collaborate with others. In this way, knowledge within the company is exchanged and makes us improve permanently."

The first pathway showcases the conceptual work by Linderman et al. (2004), suggesting that, taken together, QM and KM set positive conditions for the company's increased effectiveness. In this study, positive synergy between QM and KM explain 61\% of cases of increased POE. On the one hand, efficient QM and KM practices are robust predictors of effectiveness and efficiency of the company. On the other hand, the efficiency of those practices is complex, and not every company masters to create those positive circles.

5.2.- Quality management, values and value fit as predictors of perceived organisational effectiveness

An alternative way of creating competitive advantage, suggested by the second solution, is through adopting values related with QM and nesting those in organisational culture. An important role in this process plays employees' compliance with those values.

$\mathrm{QM}$, in its core, consists of certain values that are supposed to benefit the organisation (Hellsten \& Klefsjö, 2000). Thus, the successful implementation of QM practices depends on the implementation of certain values by the organisation. This means that QM values should be aligned with company values, company culture, and the values of its employees at all levels. The following quote of one of the managers interviewed in our research reveals the relevance of quality of the products and services but also, values management: "To achieve organizational effectiveness, the quality of the product and its production system is important. However, how employees feel integrated and involved within the organization is also very important. The company promotes these values and expects that they will be bigger and more aligned with their own personal 
values". Thus, the second configuration empirically demonstrates that the alignment between QM values, company values, and employees' values sets conditions for the increased POE.

In practice, this means that within an organisation, dedicated to quality, company culture is aligned with QM. These companies strive to obtain 100\% quality from its suppliers, improve their own production cycle, and provide benefits for its suppliers. At the company level, each employee that conform to the values of the company, creates effective work relations with suppliers, clients, and other employees; thus, increasing their own effectiveness and the effectiveness of the organisation. According to a manager interviewed states that: "Some new employees were needed when the company was at growth period. They asked employees to send CVs of friends and family members. These new candidates were hired and consequently the atmosphere improved, and additionally productivity also increased. The feeling of belonging and unity inside the company increased. Again, the company values were a good asset and even proved to be profitable in terms of economic results". In this sense, values can increase the organizational effectiveness in organizations.

As follows from literature review, some authors suggest that organizational culture based on specific values, such as customer orientation, continuous innovation, continuous improvement, employee engagement, support of senior management has positive relation with implementation of QM practices (Gimenez-Espin, JimenezJimenez \& Martínez-Costa, 2013; Page \& Curry, 2000; Lakhe \& Mohanty, 2004; Douglas \& Judge, 2001; Jabnoun \& Sedrani, 2005). Our findings are in line with previous research. It can be further inferred from analysis of values with highest factor loadings that specifically, continuous improvement, learning, creativity, working environment, team work and diligence - factors internal and external to firm - facilitate implementation of 
QM. Surprisingly, customer satisfaction, was not among those items.

\section{6.- Conclusions, limitations and future research}

QM, KM, and organisational culture have been studied separately, and have been known to provide positive impact on POE. The goal of this article was to find synergies by studying combined effects of these resources and capabilities of the company on the POE. For this reason, mixed methodology based on quantitative and qualitative data collection was used. QCA was implemented. Results indicate two causal paths for creating competitive advantage, suggesting positive interaction between QM and KM, on the one hand; and QM, value, and employees' value fit, on the other hand. In both causal paths, QM plays a significant role, hence the importance of QM in order to vouch a high POE. On the other hand, either KM neither cultural issues (i.e., values and values fit) can be neglected.

This study provides robust results, although not without limitations. Future research might extend this analysis to other countries or replicate analysis for a specific industry that is more innovative, more conservative, or more or less dependent on research and development. In the same direction, future research might investigate the role of internalisation and how pathways for POE might differ for those companies that operate or sell their products on other markets. Finally, the composition of the sample might have imposed certain limitations on the generalizability of results. At firm level, the sample was characterized by a bias toward older and smaller companies. At personal level, respondents were primarily males from strategic management department. While acknowledging this limitation, the authors are not able to speculate on how these limitations have affected the results of the study as there does not exist sufficient literature that discuss the relation between these characteristics and the topic of the study. 
It might be a direction for future research to explore other organisational values and their link to QM and POE. In this study, organisational values were divided into four categories: (1) relational, (2) development, (3) contribution, and (4) business; because these classifications are focused on organisational priorities in search of organisational excellence, which are, by thought of other authors, related to QM and KM. Also, future research might explore specific conditions that may either foster or inhibit knowledge creation from QM. 


\section{References}

Agus, A., \& Hassan, Z. (2011). Enhancing production performance and customer performance through total quality management (TQM): Strategies for competitive advantage. Procedia-Social and Behavioral Sciences, 24, 16501662.

Ahire, S. L., Golhar, D. Y., \& Waller, M. A. (1996). Development and validation of TQM implementation constructs. Decision Sciences, 27(1), 23-56.

Ahmed, P. K., Loh, A. Y., \& Zairi, M. (1999). Cultures for continuous improvement and learning. Total Quality Management, 10(4-5), 426-434.

Akgün, A. E., Ince, H., Imamoglu, S. Z., Keskin, H., \& Kocoglu, I. (2014). The mediator role of learning capability and business innovativeness between total quality management and financial performance. International Journal of Production Research, 52(3), 888-901.

Al-Hakim, L. A., \& Hassan, S. (2016). Core requirements of knowledge management implementation, innovation and organizational performance. Journal of Business Economics and Management, 17(1), 109-124.

Alegre, J., Sengupta, K., \& Lapiedra, R. (2013). Knowledge management and innovation performance in a high-tech SMEs industry. International Small Business Journal, 31(4), 454-470.

Ali, I., Rehman, K. U., Ali, S. I., Yousaf, J., \& Zia, M. (2010). Corporate social responsibility influences, employee commitment and organizational performance. African Journal of Business Management, 4(13), 2796-2801.

Barney, J. (1991). Firm resources and sustained competitive advantage. Journal of management, 17(1), 99-120.

Becerra-Fernandez, I., \& Sabherwal, R. (2001). Organizational knowledge management: A contingency perspective. Journal of Management Information Systems, 18(1), 23-55.

Brockman, B. K., \& Morgan, R. M. (2003). The role of existing knowledge in new product innovativeness and performance. Decision Sciences, 34(2), 385-419.

Cable, D. M., \& DeRue, D. S. (2002). The convergent and discriminant validity of subjective fit perceptions. Journal of Applied Psychology, 87(5), 875-884.

Cardona, P., \& Rey, C. (2008). Management by missions. Springer. 
Carneiro, A. (2000). How does knowledge management influence innovation and competitiveness? Journal of Knowledge Management, 4(2), 87-98.

Chen, C. J., \& Huang, J. W. (2009). Strategic human resource practices and innovation performance - The mediating role of knowledge management capacity. Journal of Business Research, 62(1), 104-114.

Choi, B., \& Lee, H. (2002). Knowledge management strategy and its link to knowledge creation process. Expert Systems with Applications, 23(3), 173-187.

Choy, C. S., Yew, W. K., \& Lin, B. (2006). Criteria for measuring KM performance outcomes in organisations. Industrial Management \& Data Systems, 106(7), 917-936.

Crosby, P. B. (1990). Leading: The art of becoming an executive. Military Engineer, 82(536), 37.

Darr, E. D., Argote, L., \& Epple, D. (1995). The acquisition, transfer, and depreciation of knowledge in service organizations: Productivity in franchises. Management science, 41(11), 1750-1762.

Davenport, T. H., \& Prusak, L. (1998). Working knowledge: How organizations manage what they know. Boston, MA: Harvard Business School Press.

David, W., \& Fahey, L. (2000). Diagnosing cultural barriers to knowledge management. The Academy of Management Executive, 14(4), 113-127.

Deal, T. E., \& Kennedy, A. A. (1982). Corporate cultures: The rites and rituals of organizational life. Reading/T. Deal, A. Kennedy.-Mass: Addison-Wesley, 2, 98103.

Dean, J. W., \& Bowen, D. E. (1994). Management theory and total quality: Improving research and practice through theory development. Academy of Management Review, 19(3), 392-418.

Deming, W. E. (2000). Out of the Crisis. In W. E. Deming (Ed.), Out of the Crisis (pp. 97-148). Cambridge, MA: MIT, Center for Advanced Engineering Study. (Reprinted from Out of the Crisis, by W. E. Deming, Ed., 1982, Cambridge, MA: MIT, Center for Advanced Engineering Study)

Denison, D. R. (1990). Corporate culture and organizational effectiveness. Oxford, England: John Wiley \& Sons.

Douglas, T. J., \& Judge, W. Q. (2001). Total quality management implementation and competitive advantage: the role of structural control and exploration. Academy of Management Journal, 44(1), 158-169. 
Dow, D., Samson, D., \& Ford, S. (1999). Exploding the myth: Do all quality management practices contribute to superior quality performance? Production and Operations Management, 8(1), 1-27.

Dröge, C., Claycomb, C., \& Germain, R. (2003). Does knowledge mediate the effect of context on performance? Some initial evidence. Decision Sciences, 34(3), 541568.

EFQM. (2012a). Enablers. Retrieved from http://www.efqm.org/efqmmodel/criteria/enablers

EFQM. (2012b). Results. Retrieved from http://www.efqm.org/efqmmodel/criteria/results

Feigenbaum, A. (1991). Total Quality Control. New York, NY: McGraw-Hill.

Fuentes-Fuentes, M. M., Albacete-Sáez, C. A., \& Lloréns-Montes, F. J. (2004). The impact of environmental characteristics on TQM principles and organizational performance. Omega, 32(6), 425-442.

Gimenez-Espin, J. A., Jiménez-Jiménez, D., \& Martínez-Costa, M. (2013). Organizational culture for total quality management. Total Quality Management \& Business Excellence, 24(5-6), 678-692.

Gloet, M., \& Terziovski, M. (2004). Exploring the relationship between knowledge management practices and innovation performance. Journal of Manufacturing Technology Management 15(5), 402-409.

Grant, R. M. (1996). Toward a knowledge-based theory of the firm. Strategic Management Journal, 17(S2), 109-122.

Greckhamer, T., Misangyi, V. F., Elms, H., \& Lacey, R. (2008). Using qualitative comparative analysis in strategic management research: An examination of combinations of industry, corporate, and business-unit effects. Organizational Research Methods, 11(4), 695-726.

Harari, O. (1993). Ten reasons why TQM doesn't work. Management Review, 82(1), 33.

Hellsten, U., \& Klefsjö, B. (2000). TQM as a management system consisting of values, techniques and tools. The TQM Magazine, 12(4), 238-244.

Hsu, S. H., \& Shen, H. P. (2005). Knowledge management and its relationship with TQM. Total Quality Management and Business Excellence, 16(3), 351-361.

Hung, R. Y. Y., Lien, B. Y. H., Fang, S. C., \& McLean, G. N. (2010). Knowledge as a facilitator for enhancing innovation performance through total quality management. Total Quality Management, 21(4), 425-438. 
Jabnoun, N., \& Sedrani, K. (2005). TQM, culture, and performance in UAE manufacturing firms. The Quality Management Journal, 12(4), 8.

Hung, R. Y. Y., Lien, B. Y. H., Yang, B., Wu, C. M., \& Kuo, Y. M. (2011). Impact of TQM and organizational learning on innovation performance in the high-tech industry. International Business Review, 20(2), 213-225.

Juran, J. M. (1992). Juran on quality by design: The new steps for planning quality into goods and services. New York, NY: Simon and Schuster.

Kanji, G. K. (1996). Implementation and pitfalls of total quality management. Total Quality Management, 7(3), 331-343.

Kanter, R. M. (2011). How great companies think differently. Harvard Business Review, 89(11), 66-78.

Lakhe, R. R., \& Mohanty, R. P. (1994). Total quality management: concepts, evolution and acceptability in developing economies. International Journal of Quality \& Reliability Management, 11(9), 9-33.

Leavengood, S., \& Anderson, T. R. (2011, July). Best practices in quality management for innovation performance. In Technology Management in the Energy Smart World (PICMET), 2011 Proceedings of PICMET'11: (pp. 1-9). IEEE.

Lee, H., \& Choi, B. (2003). Knowledge management enablers, processes, and organizational performance: An integrative view and empirical examination. Journal of Management Information Systems, 20(1), 179-228.

Li, Y. H., Huang, J. W., \& Tsai, M. T. (2009). Entrepreneurial orientation and firm performance: The role of knowledge creation process. Industrial Marketing Management, 38(4), 440-449.

Lim, K. K., Ahmed, P. K., \& Zairi, M. (1999). Managing for quality through knowledge management. Total Quality Management, 10(4-5), 615-621.

Lin, C., \& Wu, C. (2005). A knowledge creation model for ISO 9001: 2000. Total Quality Management \& Business Excellence, 16(5), 657-670.

Linderman, K., Schroeder, R. G., Zaheer, S., Liedtke, C., \& Choo, A. S. (2004). Integrating quality management practices with knowledge creation processes. Journal of Operations Management, 22(6), 589-607.

López-Nicolás, C., \& Meroño-Cerdán, Ã. L. (2011). Strategic knowledge management, innovation and performance. International Journal of Information Management, 31(6), 502-509. 
Malbašić, I., Marimon, F., \& Mas-Machuca, M. (2016). Is it worth having focused values? Management Decision, 54(10), 2370-2392.

Martínez-Costa, M., \& Martínez-Lorente, A. R. (2008). Does quality management foster or hinder innovation? An empirical study of Spanish companies. Total Quality Management, 19(3), 209-221.

Mas-Machuca, M., Malbašić, I., \& Marimon, F. (2017, September). The knowledge creation and organizational effectiveness: Reality or dream? In ECKM 2017. Proceedings of the 18th European Conference of Knowledge Management (Guide No. 158). Reading, England: Academic Conferences and Publishing International.

McAdam, R. (2000). Knowledge management as a catalyst for innovation within organizations: A qualitative study. Knowledge and Process Management, 7(4), 233-241.

McEvily, S. K., \& Chakravarthy, B. (2002). The persistence of knowledge-based advantage: an empirical test for product performance and technological knowledge. Strategic management journal, 23(4), 285-305.

Meso, P., Troutt, M. D., \& Rudnicka, J. (2002). A review of naturalistic decisionmaking research with some implications for knowledge management. Journal of Knowledge Management, 6(1), 63-73.

Molina, L. M., Montes, F. J. L., \& Fuentes, M. D. M. F. (2004). TQM and ISO 9000 effects on knowledge transferability and knowledge transfers. Total Quality Management \& Business Excellence, 15(7), 1001-1015.

Montes, F. J. L., Jover, A. V., \& Fernández, L. M. M. (2003). Factors affecting the relationship between total quality management and organizational performance. International Journal of Quality \& Reliability Management, 20(2), 189-209.

Nonaka, I. (1994). A dynamic theory of organizational knowledge creation. Organization Science, 5(1), 14-37.

Nonaka, I., Toyama, R., \& Konno, N. (2000). SECI, $B a$ and leadership: A unified model of dynamic knowledge creation. Long Range Planning, 33(1), 5-34.

Ooi, K. B., Teh, P. L., \& Yee-Loong Chong, A. (2009). Developing an integrated model of TQM and HRM on KM activities. Management Research News, 32(5), 477490. 
Ordanini, A., Parasuraman, A., \& Rubera, G. (2014). When the recipe is more important than the ingredients: A qualitative comparative analysis (QCA) of service innovation configurations. Journal of Service Research, 17(2), 134-149.

Page, R., \& Curry, A. (2000). TQM-a holistic view. The TQM magazine, 12(1), 11-18.

Pettigrew, A. M. (1979). On studying organizational cultures. Administrative science quarterly, 24(4), 570-581

Prajogo, D. I., \& McDermott, C. M. (2005). The relationship between total quality management practices and organizational culture. International Journal of Operations \& Production Management, 25(11), 1101-1122.

Prajogo, D. I., \& Sohal, A. S. (2001). TQM and innovation: A literature review and research framework. Technovation, 21(9), 539-558.

Ragin, C. C. (2000). Fuzzy-set social science. Chicago, IL: University of Chicago Press.

Ragin, C. C. (2006). Set relations in social research: Evaluating their consistency and coverage. Political Analysis, 14(3), 291-310.

Ragin, C. C. (2008). Redesigning social inquiry: Fuzzy sets and beyond (Vol. 240). Chicago, IL: University of Chicago Press.

Ragin, C. C., \& Fiss, P. C. (2008). Net effects analysis versus configurational analysis: An empirical demonstration. In C. C. Ragin (Ed.), Redesigning Social Inquiry: Fuzzy Sets and Beyond (pp. 190-212). Chicago, IL: University of Chicago Press.

Rashid, M. Z., \& Anantharaman, R. N. (1997). A study of corporate culture strategy and culture. Malaysian Management Review, 32(4), 25-29.

Rasula, J., Vuksic, V. B., \& Stemberger, M. I. (2012). The impact of knowledge management on organisational performance. Economic and Business Review for Central and South-Eastern Europe, 14(2), 147-168.

Rezaei, G., Mardani, A., Senin, A. A., Wong, K. Y., Sadeghi, L., Najmi, M., \& Shaharoun, A. M. (2016). Relationship between culture of excellence and organisational performance in Iranian manufacturing companies. Total Quality Management \& Business Excellence, 1-22.

Sadikoglu, E., \& Zehir, C. (2010). Investigating the effects of innovation and employee performance on the relationship between total quality management practices and firm performance: An empirical study of Turkish firms. International Journal of Production Economics, 127(1), 13-26. 
Samson, D., \& Terziovski, M. (1999). The relationship between total quality management practices and operational performance. Journal of Operations Management, 17(4), 393-409.

Schein, E. H. (1985). Organisational culture and leadership: A dynamic view. San Francisco, CA: Jossey-Bass.

Schneider, C. Q., \& Wagemann, C. (2010). Standards of good practice in qualitative comparative analysis (QCA) and fuzzy-sets. Comparative Sociology, 9(3), 397418.

Schneider, C. Q., \& Wagemann, C. (2012). Set-theoretic methods for the social sciences: A guide to qualitative comparative analysis. Cambridge, NY: Cambridge University Press.

Schneider, M. R., Schulze-Bentrop, C., \& Paunescu, M. (2010). Mapping the institutional capital of high-tech firms: A fuzzy-set analysis of capitalist variety and export performance. Journal of International Business Studies, 41(2), 246266.

Sitkin, S. B., Sutcliffe, K. M., \& Schroeder, R. G. (1994). Distinguishing control from learning in total quality management: A contingency perspective. Academy of Management Review, 19(3), 537-564.

Sousa-Poza, A., Nystrom, H., \& Wiebe, H. (2001). A cross-cultural study of the differing effects of corporate culture on TQM in three countries. International Journal of Quality \& Reliability Management, 18(7), 744-761.

Stähle, P., \& Hong, J. (2002). Dynamic intellectual capital in global rapidly changing industries. Journal of Knowledge Management, 6(2), 177-189.

Tan, C. L., \& Nasurdin, A. M. (2011). Human resource management practices and organizational innovation: Assessing the mediating role of knowledge management effectiveness. Electronic Journal of Knowledge Management, 9(2), $155-167$.

Theriou, G. N., \& Chatzoglou, P. D. (2008). Enhancing performance through best HRM practices, organizational learning and knowledge management: A conceptual framework. European Business Review, 20(3), 185-207.

Tomic, B., Spasojević Brkić, V., Karapetrovic, S., Pokrajac, S., Milanović, D. D., Babić, B., \& Djurdjevic, T. (2017). Organizational culture, quality improvement tools and methodologies, and business performance of a supply 
chain. Proceedings of the Institution of Mechanical Engineers, Part B: Journal of Engineering Manufacture, 231(13), 2430-2442.

Trivellas, P., \& Santouridis, I. (2009, December). TQM and innovation performance in manufacturing SMEs: The mediating effect of job satisfaction. In Industrial Engineering and Engineering Management, 2009. IEEM 2009. IEEE International Conference on (pp. 458-462). IEEE.

Van der Post, W. Z., \& De Coning, T. J. (1998). The relationship between organisational culture and financial performance: Some South African evidence. South African Journal of Business Management, 29(1), 30-40.

Wiig, K. M. (1995). Knowledge management methods. Arlington TX: Schema Press.

Wiig, K. M., De Hoog, R., \& Van Der Spek, R. (1997). Supporting knowledge management: A selection of methods and techniques. Expert Systems with Applications, 13(1), 15-27.

Yaniv, E., \& Farkas, F. (2005). The impact of person-organization fit on the corporate brand perception of employees and of customers. Journal of Change Management, 5(4), 447-461.

Young, G., Sapienza, H., \& Baumer, D. (2003). The influence of flexibility in buyerseller relationships on the productivity of knowledge. Journal of Business Research, 56(6), 443-451.

Zehir, C., Ertosun, G., Zehir, S., \& Müceldilli, B. (2012). Total quality management practices effects on quality performance and innovative performance. ProcediaSocial and Behavioral Sciences, 41, 273-280.

Zhao, F., \& Bryar, P. (2001, April). Integrating knowledge management and total quality: A complementary process. In 6th International Conference on ISO (Vol. 9000).

Zheng, W., Yang, B., \& McLean, G. N. (2010). Linking organizational culture, structure, strategy, and organizational effectiveness: Mediating role of knowledge management. Journal of Business research, 63(7), 763-771.

Zu, X., Robbins, T. L., \& Fredendall, L. D. (2010). Mapping the critical links between organizational culture and TQM/Six Sigma practices. International Journal of Production Economics, 123(1), 86-106. 


\section{Appendix: A description of measures utilised}

\begin{tabular}{|c|c|c|}
\hline Construct & Code & Item \\
\hline \multirow{9}{*}{$\begin{array}{l}\text { QM } \\
\text { (EFQM, } \\
2012 a, \\
2012 b)\end{array}$} & QM1 & $\begin{array}{l}\text { In my company, leaders shape the future and make it happen through their values } \\
\text { and ethics }\end{array}$ \\
\hline & QM2 & $\begin{array}{l}\text { In my company, policies, plans, objectives and processes are developed and } \\
\text { deployed to deliver the strategy }\end{array}$ \\
\hline & QM3 & $\begin{array}{l}\text { My company values their people and creates a culture that allows the mutually } \\
\text { beneficial achievement }\end{array}$ \\
\hline & QM4 & $\begin{array}{l}\text { My company plans and manages external partnerships, suppliers and internal } \\
\text { resources }\end{array}$ \\
\hline & QM5 & $\begin{array}{l}\text { My company designs, manages and improves processes, products and services to } \\
\text { generate increasing value for customers and other stakeholders }\end{array}$ \\
\hline & QM6 & $\begin{array}{l}\text { My company achieves and sustains outstanding results that meet or exceed the need } \\
\text { and expectations of their customers }\end{array}$ \\
\hline & QM7 & $\begin{array}{l}\text { My company achieves and sustains outstanding results that meet or exceed the need } \\
\text { and expectations of their people }\end{array}$ \\
\hline & QM8 & $\begin{array}{l}\text { My company achieves and sustains outstanding results that meet or exceed the need } \\
\text { and expectations of relevant stakeholders within society }\end{array}$ \\
\hline & QM9 & $\begin{array}{l}\text { My company achieves and sustains outstanding results that meet or exceed the need } \\
\text { and expectations of their business stakeholders }\end{array}$ \\
\hline \multirow{16}{*}{$\begin{array}{l}\text { KM } \\
\text { (Mas- } \\
\text { Machuca } \\
\text { et al., } \\
\text { 2017) }\end{array}$} & KM01 & $\begin{array}{l}\text { Through my own means I am able to obtain internal and external information of the } \\
\text { company }\end{array}$ \\
\hline & KM02 & Through interaction with my colleagues I find new business opportunities \\
\hline & KM03 & The employees' rotation among departments enables me sharing knowledge \\
\hline & KM04 & I share ideas with customers, suppliers and competitors \\
\hline & KM05 & The work atmosphere allows me transmitting "Know-how" to other employees \\
\hline & KM06 & I share my ideas or new concepts using comparisons or metaphors \\
\hline & KM07 & I express my opinions through dialogue with my colleagues \\
\hline & KM08 & I participate in teamworks to analyze and generate new ideas \\
\hline & KM09 & I use social networks to share information \\
\hline & KM10 & $\begin{array}{l}\text { I use data provided by the information systems of the company (ERP, CRM, SCM, } \\
\text { etc.) }\end{array}$ \\
\hline & KM11 & $\begin{array}{l}\text { The use of the external and internal information of the company helps me to take } \\
\text { decisions }\end{array}$ \\
\hline & KM12 & $\begin{array}{l}\text { I create reports based on company information such as manuals, institutional } \\
\text { documents, etc. }\end{array}$ \\
\hline & KM13 & I transfer ideas to other colleagues through presentations and documents \\
\hline & KM14 & My work/experience helps me to learn and improve in my job (learning by doing \\
\hline & KM15 & My experience in the company allows me to know the best practices performed \\
\hline & KM16 & Managers encourage experimentation / simulation of new scenarios \\
\hline \multirow{12}{*}{$\begin{array}{l}\text { Values } \\
\text { (Malbašić } \\
\text { et al., } \\
\text { 2016) }\end{array}$} & VA1_bus1 & Cost consciousness - Responsible and careful use of the company's assets \\
\hline & VA1_bus2 & Diligence - A positive attitude towards work and engagement in business activities \\
\hline & VA1_bus3 & Results achievement - Focus on outcomes or final positive effect of effort \\
\hline & VA1_bus4 & $\begin{array}{l}\text { Professionalism - Performing activities in accordance with the rules and standards } \\
\text { of the profession }\end{array}$ \\
\hline & VA2_rel1 & $\begin{array}{l}\text { Teamwork - Promoting and encouraging the spirit of oneness, togetherness, and co- } \\
\text { operation }\end{array}$ \\
\hline & VA2_rel2 & Respect for people - Respect for the values and uniqueness of each individual \\
\hline & VA2_rel3 & $\begin{array}{l}\text { Good interpersonal relationships - Harmonious and pleasant relations between } \\
\text { employees and management }\end{array}$ \\
\hline & VA2_rel4 & Working environment - Promoting positive and optimistic work environment \\
\hline & VA3_dev1 & $\begin{array}{l}\text { Innovation - Promoting and encouraging new, better, and changing solutions and } \\
\text { ways of doing things }\end{array}$ \\
\hline & VA3_dev2 & Creativity - Developing new ideas and applying innovative approaches \\
\hline & VA3_dev3 & Learning - Passion for learning and sharing ideas \\
\hline & VA3_dev4 & Continuous improvement - Striving for continuous improvements in everything we \\
\hline
\end{tabular}




\begin{tabular}{|c|c|c|}
\hline & & do \\
\hline & VA4_con1 & Environmental protection - Care for clean and healthy environment \\
\hline & VA4_con2 & $\begin{array}{l}\text { Social responsibility - Supporting a variety of efforts to improve development of } \\
\text { society }\end{array}$ \\
\hline & VA4_con3 & Integrity - Uncompromising adherence to moral values \\
\hline & VA4_con4 & Customer satisfaction - Customer delight and satisfaction drive our action \\
\hline \multirow{3}{*}{$\begin{array}{l}\text { Value fit } \\
\text { (Cable \& } \\
\text { DeRue, } \\
\text { 2002) }\end{array}$} & VF1 & $\begin{array}{l}\text { The things that I value in life are very similar to the things that my organisation } \\
\text { values }\end{array}$ \\
\hline & VF2 & My personal values match my organisation's values and culture \\
\hline & VF3 & $\begin{array}{l}\text { My organisation's values and culture provide a good fit with the things that I value } \\
\text { in life }\end{array}$ \\
\hline \multirow{5}{*}{$\begin{array}{l}\text { POE } \\
\text { (Lee \& } \\
\text { Choi, } \\
\text { 2003) }\end{array}$} & POE1 & Compared with key competitors, our company is more successful. \\
\hline & POE2 & Compared with key competitors, our company has a greater market share. \\
\hline & POE3 & Compared with key competitors, our company is growing faster. \\
\hline & POE4 & Compared with key competitors, our company is more profitable. \\
\hline & POE5 & Compared with key competitors, our company is more innovative \\
\hline
\end{tabular}

Note. Items selected after EFA are marked in grey 
Table 1. Descriptive statistics of the sample.

\begin{tabular}{|c|c|c|}
\hline & NUMBER & $\%$ \\
\hline \multicolumn{3}{|l|}{ AGE: } \\
\hline Between 21 and 30 & 1 & 1.4 \\
\hline Between 31 and 40 & 8 & 10.9 \\
\hline Between 41 and 50 & 24 & 32.9 \\
\hline Between 51 and 60 & 28 & 38.4 \\
\hline More than 61 & 12 & 16.4 \\
\hline Total & 73 & 100.0 \\
\hline \multicolumn{3}{|l|}{ SEX: } \\
\hline Female & 13 & 17.8 \\
\hline Male & 60 & 82.2 \\
\hline Total & 73 & 100.0 \\
\hline \multicolumn{3}{|l|}{ LEVEL OF EDUCATION: } \\
\hline Basic studies & 2 & 2.7 \\
\hline Professional formation & 4 & 5.5 \\
\hline University degree & 67 & 91.8 \\
\hline Total & 73 & 100.0 \\
\hline \multicolumn{3}{|c|}{ CURRENT POSITION IN THE COMPANY: } \\
\hline Operational Management & 1 & 1.4 \\
\hline Tactical Management & 19 & 26 \\
\hline Strategic Management & 53 & 72.6 \\
\hline Total & 73 & 100.0 \\
\hline \multicolumn{3}{|c|}{ TOTAL LENGTH OF SERVICE CURRENT COMPANY } \\
\hline Between 01 and 05 & 7 & 9.6 \\
\hline Between 06 and 10 & 10 & 13.7 \\
\hline Between 11 and 15 & 12 & 16.4 \\
\hline Between 16 and 25 & 27 & 36.9 \\
\hline More than 26 & 15 & 20.5 \\
\hline NA & 2 & 2.7 \\
\hline Total & 73 & 100.0 \\
\hline
\end{tabular}


Table 2. Reliability of constructs.

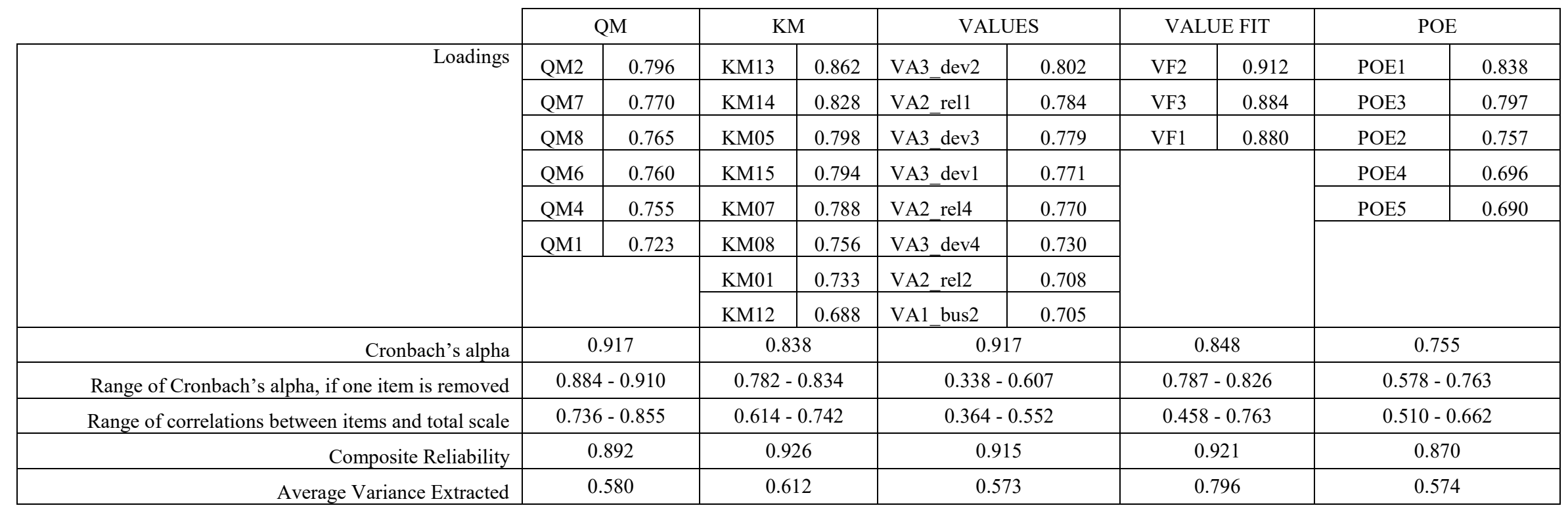


Table 3. Calibration decisions for outcome and antecedent conditions.

\begin{tabular}{|c|c|c|c|c|c|c|}
\hline & & \multicolumn{2}{|c|}{$\begin{array}{l}\text { Descriptive } \\
\text { statistics }\end{array}$} & \multicolumn{3}{|c|}{ Membership threshold values } \\
\hline & & Mean & $\begin{array}{l}\text { St. } \\
\text { Dev. }\end{array}$ & $\begin{array}{l}\text { Full non- } \\
\text { membership } \\
(0.05)\end{array}$ & $\begin{array}{c}\text { Cross- } \\
\text { over point } \\
(0.5)\end{array}$ & $\begin{array}{c}\text { Full- } \\
\text { membership } \\
(0.95)\end{array}$ \\
\hline $\begin{array}{l}\tilde{\Xi} \\
\tilde{0} \\
\stackrel{0}{0} \\
0\end{array}$ & $\begin{array}{l}\text { Perceived organisational } \\
\text { effectiveness (POE) }\end{array}$ & 0.08 & 1.01 & 1.00 & 0.00 & -1.00 \\
\hline \multirow{4}{*}{ 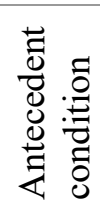 } & Quality management (QM) & 0.00 & 0.99 & 1.00 & 0.00 & -1.00 \\
\hline & Knowledge management $(\mathrm{KM})$ & 0.13 & 0.89 & 1.00 & 0.00 & -1.00 \\
\hline & Values & 0.03 & 1.01 & 1.00 & 0.00 & -1.00 \\
\hline & Values fit & 0.11 & 0.97 & 1.00 & 0.00 & -1.00 \\
\hline
\end{tabular}


Table 4. Analysis of necessary conditions.

\begin{tabular}{|r|r|r|}
\hline Conditions tested & Consistency & Coverage \\
\hline QM (qm) & $0.69(0.43)$ & $0.73(0.50)$ \\
\hline $\mathrm{KM}(\mathrm{km})$ & $0.75(0.41)$ & $0.68(0.56)$ \\
\hline $\mathrm{VA}(\mathrm{va})$ & $0.67(0.45)$ & $0.66(0.55)$ \\
\hline $\mathrm{VF}(\mathrm{vf})$ & $0.72(0.44)$ & $0.70(0.56)$ \\
\hline $\mathrm{KM}+\mathrm{QM}$ & 0.83 & 0.65 \\
\hline $\mathrm{VA}+\mathrm{VF}+\mathrm{QM}$ & 0.87 & 0.64 \\
\hline $\mathrm{VA}+\mathrm{VF}+\mathrm{KM}$ & $0.92 *$ & 0.63 \\
\hline
\end{tabular}

Notes. VA = Values; VF = Values Fit; ' + ' is a logical expression for 'or'. An expression of necessary condition is marked by *. Lowercase in parentheses means negation of condition. 
Table 5. Analysis of sufficient conditions: intermediate solution.

\begin{tabular}{|c|c|c|c|c|c|c|c|}
\hline \multirow{2}{*}{ Pathway } & \multicolumn{3}{|c|}{ Antecedents conditions } & \multicolumn{2}{c|}{ Coverage } & \multirow{2}{*}{ Consistency } \\
\cline { 2 - 7 } & QM & KM & VA & VF & Raw & Unique & \\
\hline $\mathbf{1}$ & $\bullet$ & $\bullet$ & & & 0.61 & 0.15 & 0.78 \\
\hline $\mathbf{2}$ & $\bullet$ & & $\bullet$ & $\bullet$ & 0.50 & 0.04 & 0.80 \\
\hline
\end{tabular}

Notes. Solution Coverage $=0.65$; Solution Consistency $=0.77$; VA $=$ Values; VF $=$ Values Fit. A black circle $(\bullet)$ represents a presence of condition, and a blank cell represents an ambiguous condition. 
Figure 1. Integrative research model.

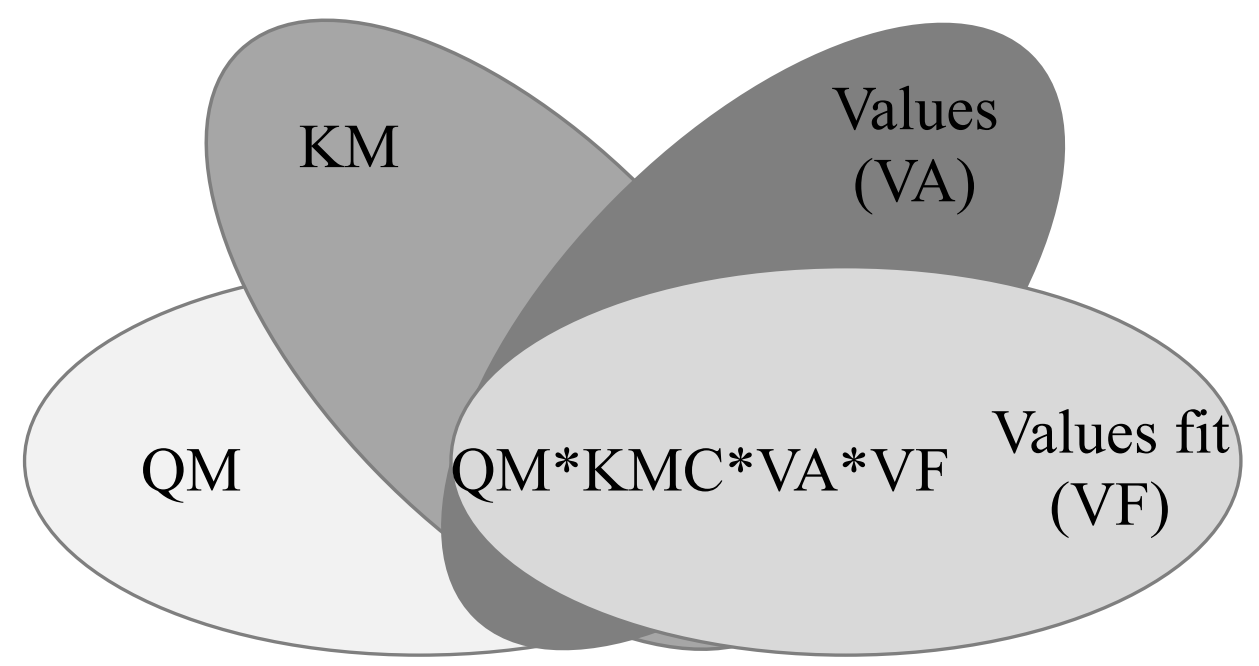

